Int. J. Odontostomat.,

15(2):403-408, 2021.

\title{
Orthodontic Records Helping to Identify A Victim of Execution
}

\author{
Registros Ortodonticos que Ayudan a Identificar una Víctima de Ejecución
}

\author{
Adriana de Moraes Correia'; Phillipe Nogueira Barbosa Alencar²; Maria Luiza Sousa Sobrinho; \\ Rhonan Ferreira Silva ${ }^{4}$; Fábio Wildson Gurgel Costa ${ }^{5}$ \& Tácio Pinheiro Bezerra ${ }^{1}$
}

\begin{abstract}
CORREIA, A. M.; ALENCAR, P. N. B.; SOBRINHO, M. L. S.; SILVA, R. F.; COSTA, F. W. G. \& BEZERRA, T. P. Orthodontic records helping to identify a victim of execution. Int. J. Odontostomat., 15(2):403-408, 2021.

ABSTRACT: Human identification is the process that identifies an individual as a unique being, differentiating him/ her from all others. The participation of Odontology in the processes of identification is fundamental in situations of human remains. This paper aims to report a case of positive identification, through dentistry, in human remains. The forensic odontologist performed a post-morten (PM) examination, which consisted of the collection of post-mortem dental findings in human bones, collection of ante-mortem (AM) dental findings in the patient's orthodontic records, and the comparison between AM and PM information. Dental elements are widely used in the processes of human identification, since they are resistant to time and to physical, chemical and mechanical impacts. Positive identification is guided by the presence of individualizing characteristics, easily detected in dental records. It is concluded that human identification through dentistry is a safe and reliable method, since dental elements have individualizing characteristics that make the process possible.
\end{abstract}

KEY WORDS: human identification, forensic anthropology, forensic dentistry.

\section{INTRODUCTION}

Human identification is the process that identifies an individual as a unique being, differentiating him/her from the others (Bel Blesa, 2012), and it may be necessary by social, legal and forensic issues (Adserias-Garriga et al., 2018).

The participation of Odontology in the processes of human identification is fundamental in situations of human remains, since the dental arches have particularities that make such a process possible (Junior et al., 2014).

According to the International Criminal Police Organization (Interpol), methods of identification can be divided into primary and secondary according to its ability to reach a significant identification. Dental analysis, fingerprints, and DNA are considered primary methods. They are the methods of choice in situations of individuals with unknown identity, due to the reliability and safety that they impart to the process (Interpol, 2019).

The dental identification process is based on the comparison of ante-mortem data, which can be obtained in dental records, study models, photographs, frontal sinus $\mathrm{X}$-rays and imaging tests to the dental data found during the human remains examination (Martinde-las-Heras et al., 2010; Prado et al., 2016; Silva et al., 2017; Moura et al., 2017). In order to obtain a successful comparison process, it is imperative that the ante-mortem information be recorded clearly and correctly (Terada et al., 2014).

${ }^{1}$ Professor of Forensic dentistry, Christus University Center - UNICHRISTUS, Ceará. Forensic Expert, Forensic Odontology Department of the Scientific Police, State of Ceará, Brazil.

${ }^{2}$ Professor of Imaginology Dentistry, Christus University Center - UNICHRISTUS, Ceará, Brazil.

${ }^{3}$ Graduation student, Christus University Center - UNICHRISTUS, Ceará, Brazil.

${ }^{4}$ Professor of Forensic dentistry, School of Dentistry, Federal University of Goias, Brazil. Forensic Expert, Forensic Odontology Department of the Scientific Police, State of Goias, Brazil.

${ }^{5}$ Professor of Imaginology Dentistry, Federal University of Ceará, Ceará, Brazil.

Received: 2020-08-05 Accepted: 2020-11-12 
The present study aims to highlight the amount of information available on orthodontic records and its importance on a case report of human identification. It differs from others case reports considering that the presence of an orthodontic retainer on the inferior teeth indicated the necessity of having the ante-mortem information collected from the orthodontic treatment.

\section{MATERIAL AND METHOD}

Case description: A human body in advanced state of decomposition was sent to a Brazilian medicolegal department in 2011 because police authorities suspected that it was from a victim of execution. The alleged victim's family was contacted to request a dental record for the purpose of accessing antemortem dental information. And it was considered essential considering that the teeth presented a lot of dental information and one of them was an orthodontic retainer, which indicated that the victim would have a lot of dental information on the orthodontic records.

The forensic protocol of body examination was followed to accomplish the anthropological investigation. The human remains were meticulously cleaned and the forensic odontologist carried out the examination in the skull and the mandible. The forensic procedure consisted of the collection of dental post-mortem data, collection of ante-mortem data and the comparison between such information. Collection of post-mortem data: The forensic odontologist performed a necroscopic examination on the human remains, right and left interproximal radiographs and photographs of the dental arches.

During the examination, the characteristics and information of the lower and upper dental arches were collected and recorded. The expert assessed the information on the anatomical (number and type of present teeth, and their presentation), therapeutic (dental loss, dental fillings, prosthesis, endodontic, and orthodontic procedures) or pathological characteristics of the teeth. Any additional trauma that related to the cause of death was also registered.

The skull and mandible were submitted to an $x$-ray interproximal examination from both sides to help in clarifying those characteristics.
Collection of ante-mortem data: Considering a lot of dental information available, and the presence of an orthodontic retainer, the forensic odontologist suggested to the police team to ask the supposed victim's family about orthodontic records that would be very useful for the identification process.

Police investigations found the alleged victim's family, who were searching for a 38-year-old man who had disappeared one year earlier. After being aware about the importance of presenting all registers that could be useful as ante-morten data, the victim's family presented an orthodontic records produced six years before the forensic exam, and composed by intra-oral photography (frontal and lateral views), panoramic radiograph, right and left bitewing radiographs.

From these orthodontic records (registers of attendance, clinical photography, dental impressions and radiographs), information such as presence of all dental units of the permanent dentition in both arches and dental treatments performed during life (restorations, prosthesis, endodontics and orthodontic treatments) was collected and tabulated on a digital sheet matching the same standard of the PM data tabulation.

\section{Comparison of ante-mortem and post-mortem} data: To do the identification comparison process, the forensic odontology confronted the AM and PM records to find discrepancies or matching data to indicate the probability to obtain a positive identification (Table I). After that, considering the amount of available data and the significant congruence between AM and PM findings, the forensic odontologist performed an specific comparison between $\mathrm{AM}$ and $\mathrm{PM}$ information through photographs of the dental arches (Fig. 1) and $A M$ and PM bite-wing radiographs of the left and right sides (Fig. 2).

Concordances were observed in all dental treatments observed in the ante-mortem and postmortem data. Considering that all 32 teeth were considered on both exams, 22 similarities were obtained and the other 10 teeth were inconclusive considering that they were burned on the PM exam. More over, the details on the images and radiographies increased the similarities between the unidentified body and the missing person (Table I). The human remains obtained a positive identification, and the body was given to the family. 
CORREIA, A. M.; ALENCAR, P. N. B.; SOBRINHO, M. L. S.; SILVA, R. F.; COSTA, F. W. G. \& BEZERRA, T. P. Orthodontic records helping to identify a victim of execution. Int. J. Odontostomat., 15(2):403-408, 2021.
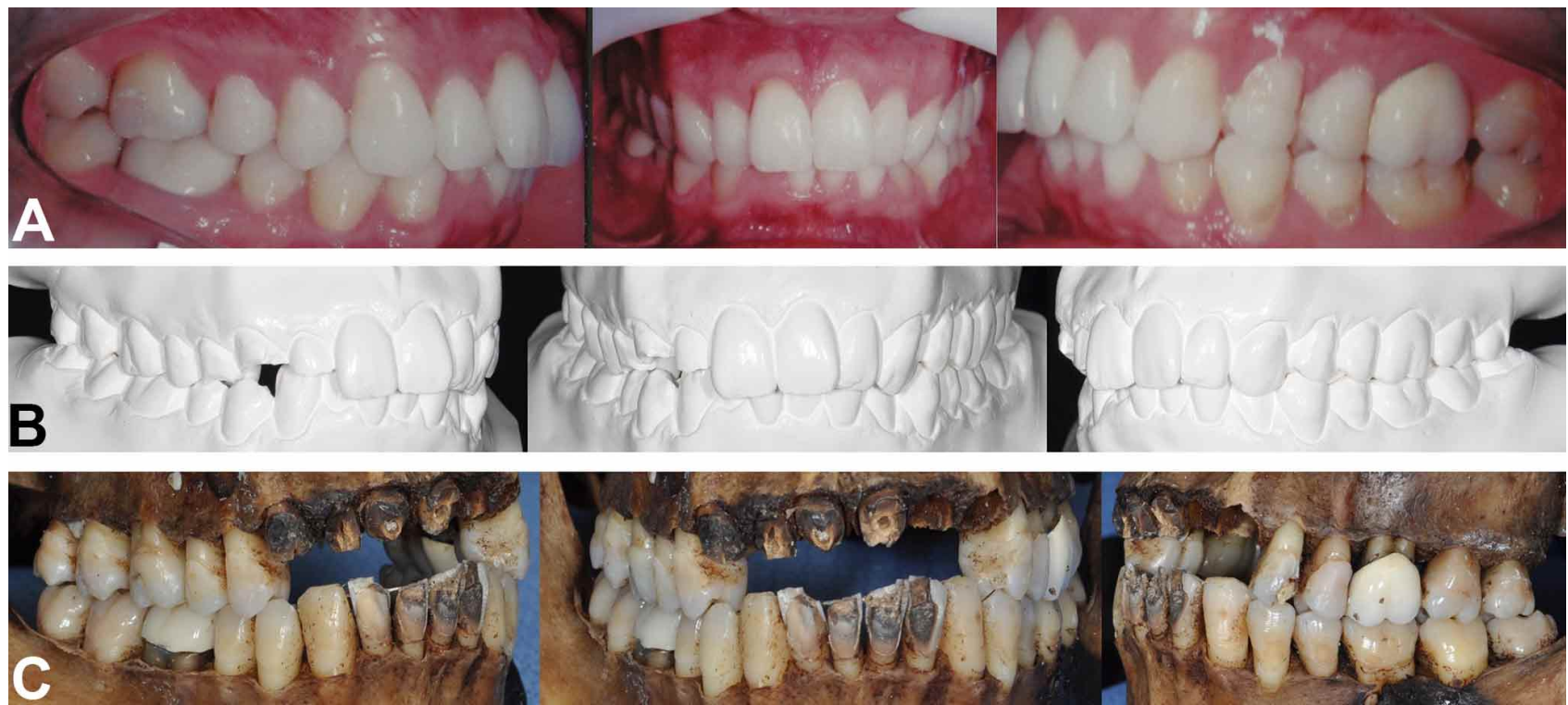

Fig. 1. Photographs ante-mortem (A - clinical; B - plast model) and post-mortem (C).

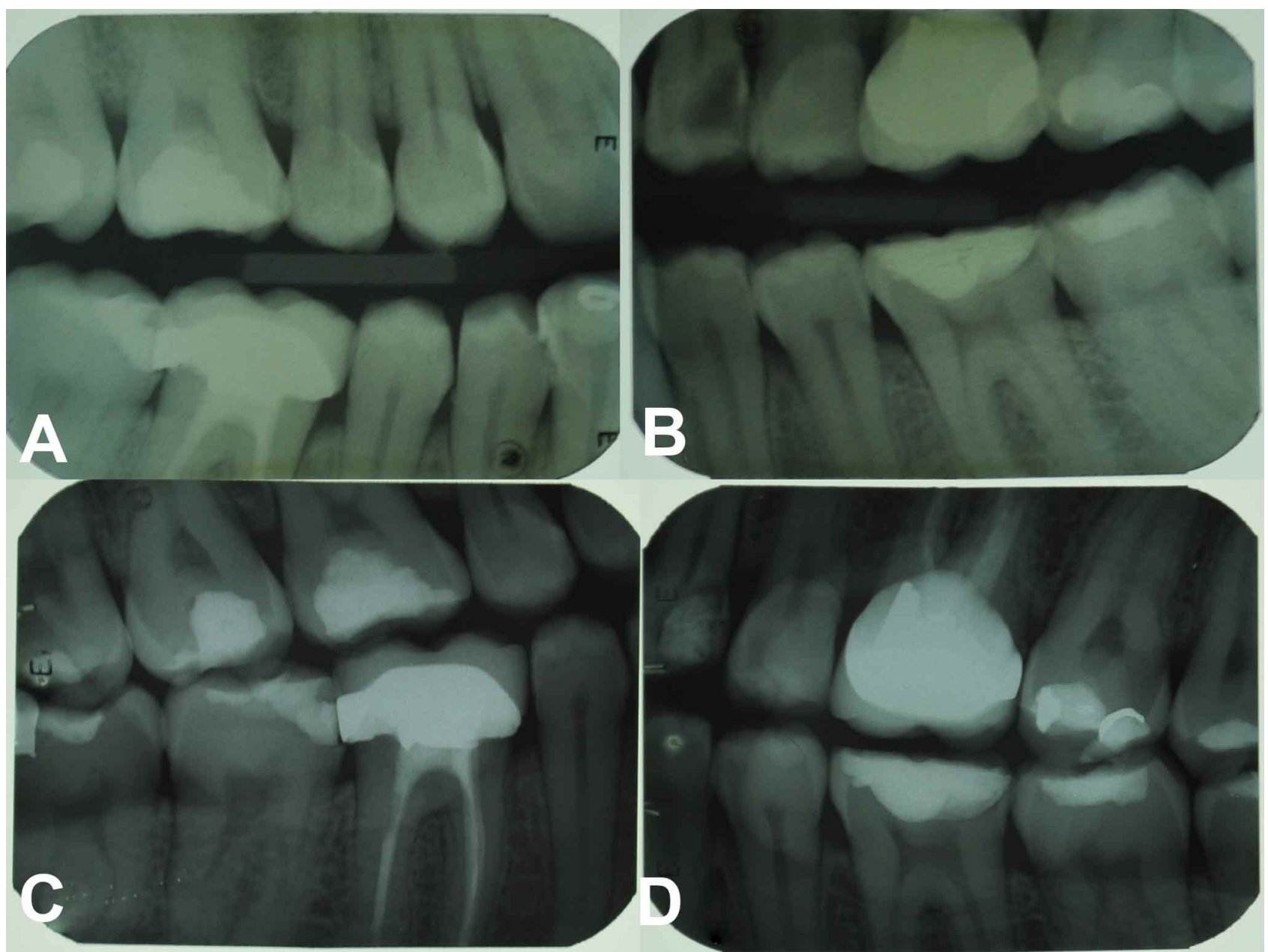

Fig. 2. Bite-wing radiographs: ante-mortem $(\mathrm{A} ; \mathrm{B})$ - and post-mortem $(\mathrm{C} ; \mathrm{D})$. 
Table I. Comparison of the ante-mortem e post-mortem data.

\begin{tabular}{|c|c|c|c|}
\hline Teeth & Ante-mortem - Dental records & Post-mortem data - Human remains & Comparison \\
\hline 18 & Composite resin filling - Occlusal & Composite resin filling - Occlusal & Similarity \\
\hline 17 & Composite resin filling - Occlusal & Composite resin filling - Occlusal & Similarity \\
\hline 16 & Composite resin filling - Occlusal & Composite resin filling - Occlusal & Similarity \\
\hline 15 & Healthy & Healthy & Similarity \\
\hline 14 & Healthy & Healthy & Similarity \\
\hline 13 & Healthy & Present, but burned & Inconclusive \\
\hline 12 & Healthy & Present, but burned & Inconclusive \\
\hline 11 & Healthy & Present, but burned & Inconclusive \\
\hline 21 & Healthy & Present, but burned & Inconclusive \\
\hline 22 & Healthy & Post-mortem loss & Inconclusive \\
\hline 23 & Healthy & Post-mortem loss & Inconclusive \\
\hline 24 & Carious lesion - Occlusal and distal & Temporary material - Occlusal and distal & Similarity \\
\hline 25 & Healthy & Healthy & Similarity \\
\hline 26 & Endodontic and prosthesis treatments & Endodontic and prosthesis treatments & Similarity \\
\hline 27 & Composite resin filling - Occlusal & Composite resin filling - Occlusal & Similarity \\
\hline 28 & Composite resin filling - Occlusal & Composite resin filling - Occlusal & Similarity \\
\hline 38 & Composite resin filling - Occlusal & Composite resin filling - Occlusal & Similarity \\
\hline 37 & Composite resin filling - Occlusal and & Composite resin filling - Occlusal and & Similarity \\
\hline 36 & Endodontic treatment & Endodontic treatment & Similarity \\
\hline 35 & Non carious cervical lesion & Non carious cervical lesion & Similarity \\
\hline 34 & Non carious cervical lesion & Non carious cervical lesion & Similarity \\
\hline 33 & Healthy & Healthy & Similarity \\
\hline 32 & Healthy & Present, but burned & Inconclusive \\
\hline 31 & Healthy & Present, but burned & Inconclusive \\
\hline 41 & Healthy & Present, but burned & Inconclusive \\
\hline 42 & Healthy & Present, but burned & Inconclusive \\
\hline 43 & Healthy & Healthy & Similarity \\
\hline 44 & Healthy & Healthy & Similarity \\
\hline 45 & Healthy & Healthy & Similarity \\
\hline 46 & Endodontic and prosthesis treatments & Endodontic and prosthesis treatments & Similarity \\
\hline 47 & Composite resin filling - Occlusal & Composite resin filling - Occlusal & Similarity \\
\hline 48 & Composite resin filling - Occlusal & Composite resin filling - Occlusal & Similarity \\
\hline
\end{tabular}

\section{DISCUSSION}

Dental elements are widely used in the processes of human identification, since they are quite resistant to time and to physical, chemical and mechanical impacts (Terada et al.). In cases of human skeleton, the soft tissues are destroyed, but dental characteristics remain accessible, including dental treatments, such as restorations, prostheses, endodontics and implants, since they are unique treatments for each individual (Kringsholm et al., 2001).

Positive human identification, established through the comparison of ante-mortem and postmortem records, has its process guided by the presence of individualizing characteristics (Fernandes et al., 2018). In forensic dentistry, these characteristics can be sought in study models, odontograms, photographs and imaging of the alleged victim, making dental records to have an important role in expert examination (Silva et al., 2004; Terada et al.). As highlighted by Terada et al. the orthodontic records are a very useful source of ante-mortem data to a human identification process. As presented on this case report, the authors obtained a positive identification using antemortem data from orthodontic treatment (Terada et al.). Among dental records, radiographic images are excellent subsidies in the processes of human identification (Nuzzolese, 2018), by the registry of particularities such as anatomy of the bone and dental structures and also dental treatments (Carvalho et al., 2009; Kannan et al., 2015). In the present case report, in addition to the photographs, the use of interproximal and panoramic radiographs was essential in the 
success of visualization of coincidental points of the ante-mortem and post-mortem data.

To identify a body by dental records it is not necessary to have a minimum number of coincidental points to establish a positive identity as in finger prints identification; the vast potential of individual coincident points between AM and PM exams some times are much more significant than a number o individual points (Acharya et al., 2003; Moraes et al., 2013). In this case report, the patient presented two dental units with postmortem loss and some dental units with signs of destruction by the action of fire, and it was not possible to compare them with the ante-mortem records. This situation did not prevent the positive identification because other dental units presented relevant coincidences, such as the type of dental treatment and the design of restorations, prostheses and endodontics in the radiographic images.

Regarding divergent points, it was observed that the first left superior premolar had a carious lesion registered in ante-mortem left interproximal radiography and registered with provisional material in the human bone. This divergence, however, does not make the identification impaired, since the victim may have performed the provisional restorative procedure after the interproximal radiographic taking.

Human identification through Forensic Dentistry has proven to be an effective, practical, low-cost, and fast method, resulting in agility in the process. It can be used in all situations where ante-mortem and postmortem records are available (Acharya et al.; Moraes et al.), and it makes the use of other identification methods that are slower or more expensive unnecessary (Silva et al., 2011).

It is concluded that human identification through Forensic Dentistry is a safe and reliable method, since dental elements have individualizing characteristics that make the process possible, as long as there are adequate and accurate ante-mortem records.

CORREIA, A. M.; ALENCAR, P. N. B.; SOBRINHO, M. L. S.; SILVA, R. F.; COSTA, F. W. G. \& BEZERRA, T. P. Registros ortodónticos que ayudan a identificar una víctima de ejecución. Int. J. Odontostomat., 15(2):403-408, 2021.

RESUMEN: La identificación humana es el proceso que identifica a un individuo como un ser único, diferenciándolo de todos los demás. La participación de la Odontología en los procesos de identificación es fundamental en situa- ciones de restos humanos. Este trabajo tiene como objetivo reportar un caso de identificación positiva, a través de la odontología, en restos humanos. El odontólogo forense realizó un examen post-morten (PM), que consistió en la recolección de hallazgos dentales post-mortem en huesos humanos, recolección de hallazgos dentales ante-mortem (AM) en los registros de ortodoncia del paciente y la comparación entre AM y Información de PM. Los elementos dentales son ampliamente utilizados en los procesos de identificación humana, ya que son resistentes al tiempo y a los impactos físicos, químicos y mecánicos. La identificación positiva está guiada por la presencia de características individualizantes, que se detectan fácilmente en los registros dentales. Se concluye que la identificación humana a través de la odontología es un método seguro y confiable, ya que los elementos dentales tienen características individualizantes que hacen posible el proceso.

PALABRAS CLAVE: Identificación humana, antropología forense, odontología forense.

\section{REFERENCES}

Acharya, A. B. \& Taylor, J. A. Are a minimum number of concordant matches needed to establish identity in forensic odontology? $\mathrm{J}$. Forensic Odontostomatol., 21(1):6-13, 2003.

Adserias-Garriga, J.; Thomas, C.; Ubelaker, D.H. \& Zapico, S. C. When forensic odontology met biochemistry: Multidisciplinary approach in forensic human identification. Arch. Oral Biol., 87:714, 2018.

Bel Blesa, A. La odontología forense en las Fuerzas Armadas: Una asignatura pendiente. Sanid. Mil., 67(4):375-80, 2012.

Carvalho, S. P. M.; Silva, R. H. A.; Lopes-Júnior, C. \& Peres, A. S. Use of images for human identification in forensic dentistry. Radiol. Bras., 42(2):125-30, 2009.

Fernandes, M. M.; Silva, R. F.; Botelho, T. D. L.; Lima, R.; Tinoco, R. \& Fontanella, V. Taurodontism and its forensic value?: a case report. J. Forensic Odontostomatol., 36(36):40-3, 2018.

Interpol. Disaster Victim Identification (DVI). Lyon, Interpol, 2019. Available from: https://www.interpol.int/en/How-we-work/ Forensics/Disaster-Victim-Identification-DVI.

Junior, E. F.; Legal, D.O.; Claudio, L. \& Moura, L. A importância dos arcos dentários na identificação humana. Rev. Bras. Odontol., 71(1):22-7, 2014.

Kannan, A.; Sathasivasubramanian, S.; Elumalai, M.; Manigandan, T. \& Sumathy, C. Forensic radiology in dentistry. J. Pharm. Bioallied Sci., 7(5):262, 2015.

Kringsholm, B.; Jakobsen, J. \& Sejrsen, B.; Gregersen, M. Unidentified bodies / skulls found in Danish waters in the period 1992-1996. Forensic Sci. Int., 123(2):150-8, 2001.

Martin-de-las-Heras, S.; Valenzuela, A.; Luna. J. D. \& Bravo, M. The utility of dental patterns in forensic dentistry. Forensic Sci. Int., 195:166.e1-e5, 2010.

Moraes, Z. M.; Barbieri, A. A.; Francesquini Júnior. L.; Daruge Júnior, E.; Scoralick, R. A. \& Naressi, S. C. M. Identificação humana por meio do estudo de imagens radiográficas odontológicas: relato de caso. Rev. Odontol. UNESP, 42(1):67-71, 2013.

Moura, R. N. V.; Ferreira. E. F.; Coste, S. C.; Corradi, L. M. \& Travassos, D. V. Identifying missing people: the contribution of forensic dentistry and DNA. Rev. Odontol. UNESP, 46(6):313-8, 2017. 
CORREIA, A. M.; ALENCAR, P. N. B.; SOBRINHO, M. L. S.; SILVA, R. F.; COSTA, F. W. G. \& BEZERRA, T. P. Orthodontic records helping to identify a victim of execution. Int. J. Odontostomat., 15(2):403-408, 2021.

Nuzzolese, E. Dental autopsy for the identification of missing persons. J. Forensic Dent. Sci., 10(1):50-4, 2018.

Prado, F. B.; Freira, A. R.; Rondon, B. C. S.; Costa, S. T.; Rossi, C. A. \& Daruje Júnior, E. Analysis of the frontal sinus morphology and the titanium plates shape in skull fracture for human identification. Int. J. Odontostomat., 10(2):303-8-2016.

Silva, R. F.; Chaves, P.; Paranhos, L. R.; Lenza, M. A. \& Daruge Júnior, E. Utilização de documentação ortodôntica na identificação humana. Dent. Press J. Orthod., 16(2):52-7, 2011.

Silva, R. F.; Felter, M.; Tolentino, P. H. M. P.; Rodrigues, L. G.; Andrade, M. G. B. A.; Palomeque, A. M. P. \& Sassi, C. Importancia pericial de los modelos de yeso odontolgicos para la identificación de cuerpo putrefacto - Relato de caso. Int. J. Odontostomat., 11(3):273-8, 2017.

Silva, R. H. A.; Pereira, S. D. R.; Daruge, E.; Daruge Júnior, E. \& Francesquini Júnior, L. S. Confiability of the forensic dental in human identification. Robrac, 13(35):46-50, 2004.

Terada, A. S. S. D.; Araujo, L. G.; Paranhos, L.R.; Guimarães, M. A.; Silveira, T. C. P. \& Silva, R. H. A. Orthodontic use of documentation in identification of a skeletonized body in legal dental practice. Int. J. Odontostomat., 8(1):41-6, 2014.
Corresponding author:

Tácio Pinheiro Bezerra

Rua Israel Bezerra, 1033

ap 501, São João do Tauape

Fortaleza, 60.135-460, CE

BRAZIL

E-mail: taciopb@gmail.com 